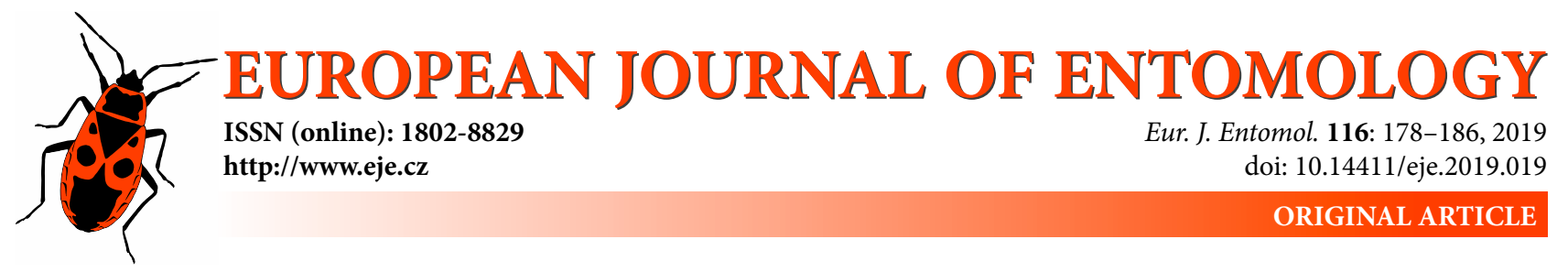

\title{
Niche width and niche specialization in four species of ladybirds (Coleoptera: Coccinellidae) co-occurring in the same habitat
}

\author{
Jean-François GodeaU ${ }^{1}$, Piotr CeryngieR ${ }^{1}$ and Jean-Louis HeMPtinNE² \\ ${ }^{1}$ Faculty of Biology and Environmental Sciences, Cardinal Stefan Wyszyński University, Wóycickiego 1/3, 01-938 Warsaw, \\ Poland; e-mails: jfgodeau@gmail.com, p.ceryngier@uksw.edu.pl \\ ${ }^{2}$ Laboratoire Évolution et Diversité Biologique, UMR 5174 CNRS, Université Toulouse 3, IRD, 118, Route de Narbonne, \\ 31062 Toulouse Cedex 9, France; e-mail: jean-louis.hemptinne@univ-tlse3.fr
}

Key words. Coccinellidae, Calvia decemguttata, Calvia quatuordecimguttata, Calvia quindecimguttata, Sospita vigintiguttata, diet, frass analysis, food niche, individual specialization

\begin{abstract}
We investigated food niches, diet diversity and individual food specialization of the larvae and adults of four species of ladybirds, Sospita vigintiguttata (L.), Calvia quindecimguttata (F.), C. quatuordecimguttata (L.) and C. decemguttata (L.), cooccurring in European alder carr forests. The first two species are considered to be strict habitat specialists associated with alders (Alnus spp.) in marshy forests and the other two are less habitat-specialized, inhabiting various deciduous trees and shrubs. Our investigations were based on the analysis of food remains in frass produced by field-collected ladybirds. In each of the species studied, adults had more diversified diets than larvae based on Levins' $D$ index of diversity. The most diverse diet recorded for adults was that for S. vigintiguttata followed by $C$. quatuordecimguttata, C. quindecimguttata and C. decemguttata. The diversity of larval diet was higher for the habitat specialists, $C$. quindecimguttata and S. vigintiguttata, than for the more habitat-generalists Calvia decemguttata and C. quatuordecimguttata. Although the main type of prey recorded for both adults and larvae of each of the species studied was aphids, other types of prey made up a relatively high part of the diet of different species/stage combinations. Psylla alni (L.), for example, was frequently recorded in the frass of adults and larvae of S. vigintiguttata and of adults of C. quatuordecimguttata and chrysomelid larvae commonly in the frass of adults and larvae of C. quindecimguttata. Quite a high proportion of the frass of all the species studied contained the remains of Psocodea. The niche width of adults was broader than that of larvae except in C. quindecimguttata in which it was the opposite. The larval niches of the strict habitat specialists, C. quindecimguttata and S. vigintiguttata, were broader than those of the less habitat-specialists $C$. decemguttata and $C$. quatuordecimguttata. Adults of all the species studied showed relatively higher levels of food specialization than larvae, except for $C$. quindecimguttata. The results of this study indicate that ecological specialization is a complex phenomenon and habitat specialization does not imply food specialization.
\end{abstract}

\section{INTRODUCTION}

Niche width and niche specialization have been studied by ecologists for a long time (Colwell \& Futuyma, 1971; Pielou, 1972; Schoener, 1974; Hutchinson, 1978; Soberón, 2007). They are associated with a range of resources (e.g. habitat, shelter, food) that are used in space and time by organisms. If a population utilizes a narrow range of resources, it is called a specialist, in contrast to generalists that utilize a wider ranges of resources. The niches may be considered at various levels, such as species, population or individual, with the higher-level niche being the sum of the lower levels. For example, the niche of a population will be the sum of the niches of all individuals (Costa et al., 2015).

In measuring the width of a trophic niche, the range of different types of food consumed has to be determined. However, simple assessments based on field or laboratory observations of food intake by individuals are far from pre- cise. More detailed methods should be used to assess comprehensively the food requirements and preferences of individuals, populations and species in order to measure the width of their trophic niches and degree of specialization.

The increasing number of studies addressing the question of food specialization stress the importance of studying this issue at various scales (Bolnick et al., 2003). At the individual level, these authors define an individual specialist as "an individual whose niche is substantially narrower than its population's niche for reasons not attributable to its sex, age or discrete morphological group". Hence, a so-called generalist may actually consist of a continuum of specialized individuals. In their review, Bolnick et al. (2003) list 93 species of animals, in which individual specialization is clear and claim that it is a widespread but underestimated phenomenon in nature, often neglected by ecologists. Mainly due to the individual-based approach to 
niche studies, a simple assumption that a generalist species is made up of generalist individuals has been questioned. However, as emphasized recently (Costa et al., 2015), this topic has not been investigated enough in specialist species. Research on food and/or habitat niche specialization ought to be intensified in order to document data sets across taxa.

Although pioneers of the niche concept even used ladybirds as an example (Johnson, 1910; Richards, 1926; Elton, 1927), it is still often difficult to decide whether a species of ladybird is a specialist or a generalist (Hodek et al., 2012). Measuring the niche width of a given species using spatial (habitat, host plant), temporal or known prey preferences (Honěk \& Rejmánek, 1982; Nedvěd, 1999; Snyder, 2009) may result in different conclusions. Therefore, the assumption that a habitat-associated species is also a food specialist should always be carefully investigated and the level of specialization stated.

The food range and preferences of ladybirds have been studied for a long time in relation to biological control of aphids, coccids, adelgids and other pests (Majerus, 1994; Obrycki \& Kring, 1998; Hodek \& Evans, 2012). Lists of the prey consumed, sometimes with their assessment as essential food, have been published for some predatory ladybirds, mainly very common generalists (Blackman, 1965; Ricci, 1986a; Albuquerque et al., 1997; Obrycki et al., 1997; Kalushkov, 1998; Triltsch, 1999; Rana et al., 2002; Kalushkov \& Hodek, 2005; Ricci et al., 2005), but also some rarer and more specialized species (Ricci, 1986b; Palmeri et al., 1996; Kalushkov \& Hodek, 2001; Ricci \& Ponti, 2005; Florek et al., 2011). Nevertheless, the trophic niches of many species remain poorly known, with none or only few prey documented (Weber \& Lundgren, 2009).

This study investigates food ranges and trophic niches of four ladybird species found in one specific habitat, alder carr forest. Two of these species, Calvia quindecimguttata (Fabricius) and Sospita vigintiguttata (L.), are closely associated with alder (Alnus spp.) trees and considered rare in Europe (Adriaens et al., 2015; Nedvěd, 2015). The remaining two, Calvia decemguttata (L.) and C. quatuordecimguttata (L.), are usually more common and less habitat-specialized, inhabiting various deciduous trees and shrubs. There is some data that indicates the habitat specialists, $C$. quindecimguttata and $S$. vigintiguttata, are also food specialists. The former is recorded as a specialized predator of immature stages of leaf beetles (Chrysomelidae) (Kanervo, 1940), while the latter a specialist on psyllids (Palmeri et al., 1996). Psyllids are also found to be essential food of C. quatuordecimguttata (Semyanov, 1980; Palmeri et al., 1996).

The main goals of this paper were (1) to determine the food niches and diet diversity of adults and larvae of three species of Calvia and S. vigintiguttata collected in alder carr forest and (2) to measure their individual food specialization. To meet these goals, we analysed food remains in frass produced by individual ladybirds collected in the field. The method used here draws on previous studies on the identification of the diet based on gut and frass contents (Conrad, 1959; Putman, 1964; Triltsch, 1999; Davidson \&
Evans, 2010) and our first exploratory analyses performed in 2010 (Florek et al., 2011).

\section{MATERIAL AND METHODS}

\section{Sample collection}

All ladybirds and prey were collected in alder carr forest in central Poland (Kampinos National Park, 52 ${ }^{\circ} 19^{\prime} 35.1^{\prime \prime} \mathrm{N}$, $20^{\circ} 49^{\prime} 13.7^{\prime \prime} \mathrm{E}$ ), except for few adults of two species (seven C. quatuordecimguttata and five $S$. vigintiguttata) that were opportunistically collected in western France (Clisson, $47^{\circ} 05^{\prime} 52.0^{\prime \prime} \mathrm{N}$ $1^{\circ} 12^{\prime} 35.9^{\prime \prime} \mathrm{W}$ ) in June 2013 in order to supplement the data set. They were collected in the same type of habitat as in Poland, and we decided to include them in the main data set after verifying that the composition of their diets did not differ significantly from that recorded for these two species in the main data set [C. quatuordecimguttata: $\mathrm{F}_{[1,10]}=2.53(\mathrm{p}=0.05) ;$ S. vigintiguttata: $\mathrm{F}_{[1,18]}=$ $1(\mathrm{p}=0.426)]$. This was done using a permutational multifactorial analysis of variance with one factor and a Bray-Curtis distance matrix (function adonis 2 form the $\mathrm{R}$ package Vegan).

Adults and 4th instar larvae of the four species of ladybirds were collected in the field using a $1 \mathrm{~m} \times 1 \mathrm{~m}$ beating tray. Invertebrates were dislodged from the branches of black alder (Alnus glutinosa (L.) Gaertner) above the tray by beating them with a wooden stick. Field sampling occurred from the second half of April until the first half of August. The whole process, from field sampling to identification of prey remains and database organization, was time-consuming, therefore the data set was progressively compiled over a period of several years (2011-2014). Nevertheless, 82 samples ( $88 \%$ of the data set) were collected between April and July during the first 3 years (2011-2013) and only 11 additional larvae of Calvia quindecimguttata were added later. The samples, therefore, were all collected between the end of spring and early summer when the different types of prey were most abundant, although the prey densities were not precisely measured.

Comprehensive details of the samples are provided in the supplementary material of this paper, along with a graphical representation of the phenology of the data.

We collected the potential types of prey from alder trees in June 2013 for comparison with the remains found in ladybird frass. Collected invertebrates were identified to species or a higher taxonomic level, parts of their body were prepared on slides and photographed. The following taxa were found: Pterocallis alni (De Geer) (Aphididae); Clethrobius comes (Walker) (Aphididae); Psylla alni (L.) (Psyllidae); Plagiosterna aenea (L.) (Chrysomelidae); Agelastica alni (L.) (Chrysomelidae); Galerucella spp. (Chrysomelidae); Metylophorus nebulosus (Stephens) and other taxa psocids (Psocodea); Alnetoidea alneti (Dahlbom) and other taxa of leafhoppers (Cicadellidae). We collected also some Thysanoptera, Heteroptera, Cicadomorpha and Acarina but did not include them in this study.

\section{Preparation of frass}

Field-collected ladybirds were transferred to the laboratory and put individually into clean Petri dishes. A sucrose solution dampened paper was added to each Petri dish to prevent starvation. After $48 \mathrm{~h}$ the ladybird faeces present in the dishes were collected and placed in a drop of water on a glass slide, teased apart, examined microscopically and photographed.

\section{Elaboration of picture database}

The process of identification and compiling of the database involved obtaining 2316 pictures tagged with as many pertinent features as possible, from general tags (e.g. tarsus, eye, cuticle) to the taxa they belonged to (e.g. processus terminalis of aphids, 
micropyle of ladybird eggs, forked claws of Psocodea species). We recognized specific features of particular prey by comparison with our reference collection of potential prey. The combination of sample IDs, picture IDs and tags were imported into R to build up the database.

The prey retained in the analysis were those we could identify and were pertinent to our purpose. We did not use remains found in frass such as pollen (although sometimes numerous) or those that could not be identified. The different types of prey record are: Acari, Aphidoidea, Coccinellidae larvae (intraguild predation), Chrysomelidae larvae, Cicadomorpha, arthropod egg, Coccinellidae eggs (intraguild predation), Psocodea, Psylla alni and Thysanoptera.

\section{Diet diversity and niche indices}

The computation of all of the following indices was done using functions in the statistical package $\operatorname{RInSp}$ (ver. 1.1, 2015; Zaccarelli et al., 2013).

The diversity of the diet of each species (adults and larvae separately or grouped) was measured using Levins' diversity index:

$$
D=1-\frac{1}{\sum_{j} q_{j}^{2}}
$$

where $q_{j}$ is the mean proportion of each of the aforementioned resources $j$ consumed by all individuals $i$ of one species, as provided by the function pop.diet (Bolnick et al., 2002; Zaccarelli et al., 2013):

$$
q_{j}=\overline{p_{i j}} \text { where } p_{i j}=\frac{n_{i j}}{\sum_{j} n_{i j}}
$$

Diet width was obtained from the same function and is simply the number of different types of prey identified per species. Obviously, this metric is a proxy of the diet width and should be carefully interpreted since it could be related to sample size. However, we make the assumption that, except for Calvia decemguttata adults $(\mathrm{n}=3)$, we collected enough samples to determine, although incompletely, the main types of prey consumed by the ladybirds in the restricted habitat and time range investigated.

To depict the general pattern of the compositions of their diet, the proportions of the different types of prey in frass of larvae and adults of each species were calculated. We approximated the amount of each type of prey within a sample from the number of picture tags, although it could be biased in various ways. For example, detection and identification is dependent on the type of prey; small prey (e.g. aphid larvae) are more likely to be completely eaten than large prey (e.g. chrysomelid larvae). However, this uncontrolled error was considered to be the same for all the species studied.

The total niche width (TNW $\left.=-\Sigma_{j} q_{j} \ln \left(q_{j}\right)\right)$ and its two components, between individual component (BIC) and within individual component (WIC), were calculated using the function WTdMC, which is an adaptation of Roughgarden's formulas (Roughgarden, 1972; Bolnick et al., 2002). As described in these two papers, the ratio $\mathrm{WIC} / \mathrm{TNW}$ is a measure of inter-individual variation in terms of diet: values near 1 indicate a high overlap in diet composition between individuals, while values approaching 0 indicate decreasing inter-individual overlap and high individual specialization. However, as emphasized by Bolnick et al. (2002), this metric can lead to biased estimates of diet variation for categorical data, since it is based on the Shannon measure of diversity. We therefore also used the index of individual specialization (IS), calculated as the average of individuals' proportional similarity indices $\left(P S_{i}\right)$. Each $P S_{i}$ 's expresses the pairwise overlap of the niche distribution of individuals and the sampled population:
$P S_{i}=1-0.5 \Sigma_{j}\left|p_{i j}-q_{j}\right|$, where $p_{i j}$ is the frequency of category $j$ in individual $i$ 's diet, and $q_{j}$ is the frequency of category $j$ in the population as a whole. The $P S_{i}$ index will be 1 when individuals consume the same proportions of different types of prey as the population as a whole and it will be less than 1 in the case of individual specialization. In order to assess the statistical significance of $P S_{i}$ we generated, through Monte Carlo resampling, 10,000 simulated populations from the original data set, each of which had a number of individuals equal to the number in the real population to each of which was randomly assigned diet items from the population's resource distribution, yielding a null model corresponding to a population composed of generalist individuals. The index $P S_{i}$ was then recalculated for each resampled data set: the proportion of resampled populations that had index values lower than the observed one corresponds to a non-parametric pvalue of the observed IS. The index and the statistics were calculated using function PSicalc.

All calculations were done in R 3.3.1, with RStudio Version 0.99 .892 as script editor and Linux operating system (Kubuntu 14.04 LTS).

\section{RESULTS}

A total of 103 samples were collected, prepared and examined. Ten of them did not contain any recognizable remains. They mainly belonged to adults sampled early in the season, which were essentially eating pollen or to larvae, which were probably freshly moulted and had empty guts. The data set used in this paper is therefore made of 93 samples (Table 1) and 10 types of prey.

Table 1. Number of adults and larvae of the four species used in this study.

\begin{tabular}{lcc}
\hline & Adult & Larvae \\
\hline Sospita vigintiguttata & 20 & 8 \\
Calvia quindecimguttata & 9 & 28 \\
Calvia quatuordecimguttata & 12 & 6 \\
Calvia decemguttata & 3 & 7 \\
\hline
\end{tabular}

\section{Diet diversity}

At the species level, with the results for adults and larvae pooled, the four species ate from 8 to 10 of the 10 types of prey that were identified in frass and Levins' diversity index ranged from 1.72 to 3.42 (Table 2).

For each species, the diet diversity was always higher for adults than larvae, although the richness of different types of prey was higher for larvae of $C$. quindecimguttata and C. decemguttata than for the adults of these species (Table 2). The most diverse diet recorded for adults was that of $S$. vigintiguttata $(\mathrm{D}=3.78)$ and of larvae of $C$. quindecimguttata $(\mathrm{D}=2.52)$.

At the individual level, diet diversity was much lower. The number of different types of prey ranged from 1 to 4 per sample, with the lowest average of 1.2 for the larvae of C. quatuordecimguttata and the highest average of 2.4 for larvae of $C$. decemguttata (Table 2).

\section{Proportion of the prey items found in frass}

The mean proportion of tags of the different kinds of prey of each species and stages revealed a clear dominance of aphids (range for larvae and adults taken separately 
Table 2. Diet diversity parameters recorded for adults, larvae and both together. R - richness (i.e. number of different types of prey); $\mathrm{D}-$ Levins' D index of diversity; meanlndR - mean individual richness of different types of prey.

\begin{tabular}{|c|c|c|c|c|c|c|c|c|}
\hline & \multicolumn{3}{|c|}{ Adults } & \multicolumn{3}{|c|}{ Larvae } & \multicolumn{2}{|c|}{ Both } \\
\hline & $\mathrm{R}$ & $\mathrm{D}$ & meanlndR & $\mathrm{R}$ & $\mathrm{D}$ & meanlndR & $\mathrm{R}$ & $\mathrm{D}$ \\
\hline Sospita vigintiguttata & 8 & 3.78 & 1.6 & 6 & 2.32 & 2.1 & 9 & 3.42 \\
\hline Calvia quindecimguttata & 6 & 2.69 & 1.8 & 9 & 2.52 & 1.8 & 10 & 2.62 \\
\hline Calvia quatuordecimguttata & 8 & 3.43 & 2.3 & 2 & 1.52 & 1.2 & 8 & 2.74 \\
\hline Calvia decemguttata & 5 & 2.15 & 2.0 & 7 & 1.53 & 2.4 & 9 & 1.72 \\
\hline
\end{tabular}

$41-80.1 \%$ ), but other types of prey can also be well represented, particularly in the diet of adults (Fig. 1).

The psyllid Psylla alni made up $25.4 \%$ and $16.1 \%$ of the different types of prey, respectively, of adults and larvae of $S$. vigintiguttata, and $23.9 \%$ of that of adults of C. quatuordecimguttata. We identified remains of chrysomelid larvae in the frass of C. quindecimguttata, which made up $13.6 \%$ of the diet of adults and $8.2 \%$ of that of larvae. This prey was not recorded in the diet of the adults of the other species and rarely in that of the larvae of $C$. decemguttata $(2.6 \%)$ and $S$. vigintiguttata $(0.8 \%)$. Psocodea were recorded as prey of adults of each of the species (range 1.8-12.5\%) and of larvae of three species (range 8.6-14.2\%). No remains of ladybird eggs were recorded in the frass of larvae of any of the species and low amounts of other arthropod eggs only in larvae of two species (C. decemguttata and C. quindecimguttata).

\section{Niche width and the measures of individual specialization}

The niche widths (TNW) of adults and larvae of each species are shown in Fig. 2. For three species, the niche

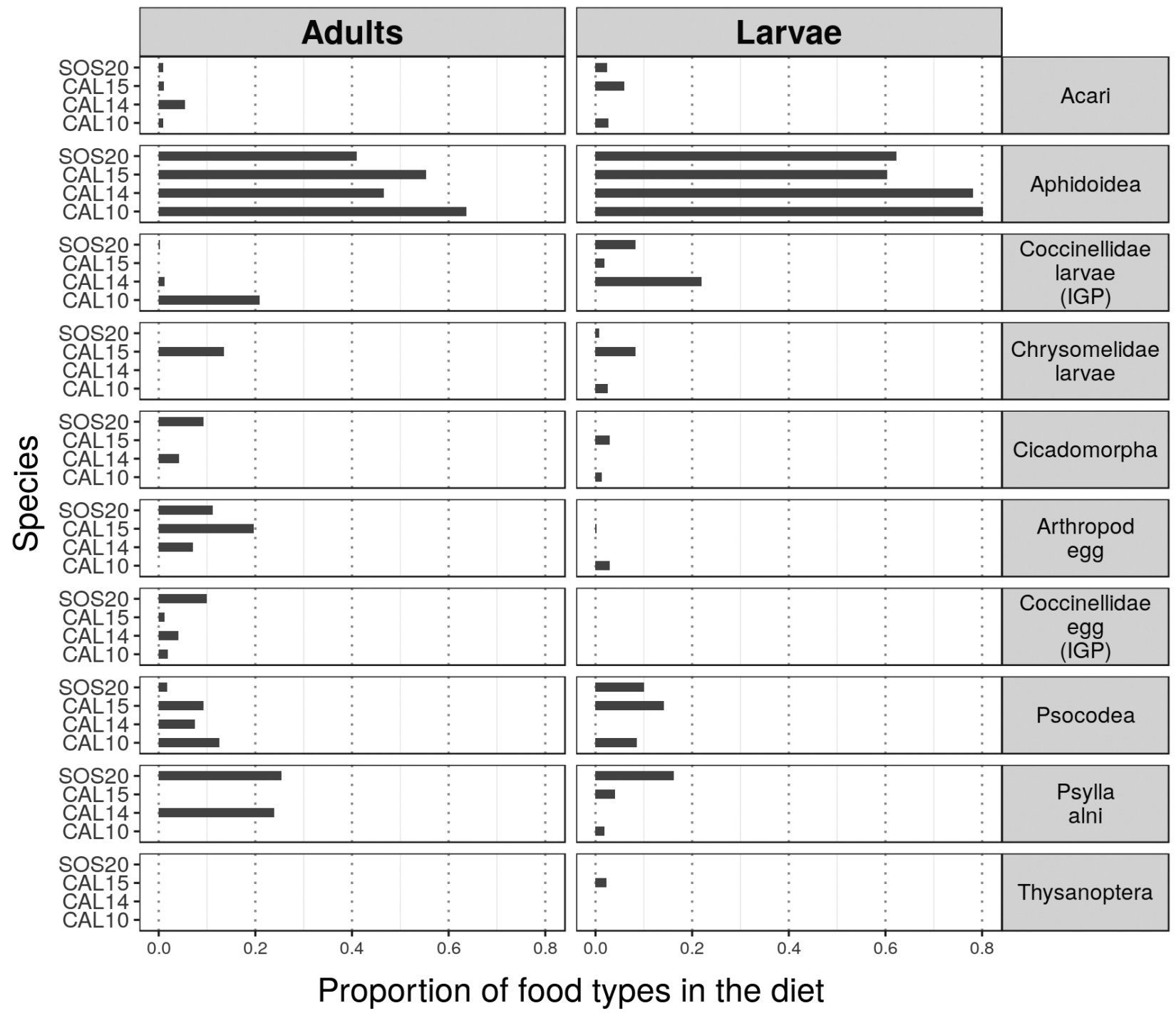

Fig.1. Mean proportions of the different types of prey in the diets of adults and larvae of the four species of ladybirds studied. IGP: intraguild predation. Species symbols: SOS20 - Sospita vigintiguttata, CAL15 - Calvia quindecimguttata, CAL14 - Calvia quatuordecimguttata, CAL10 - Calvia decemguttata. 


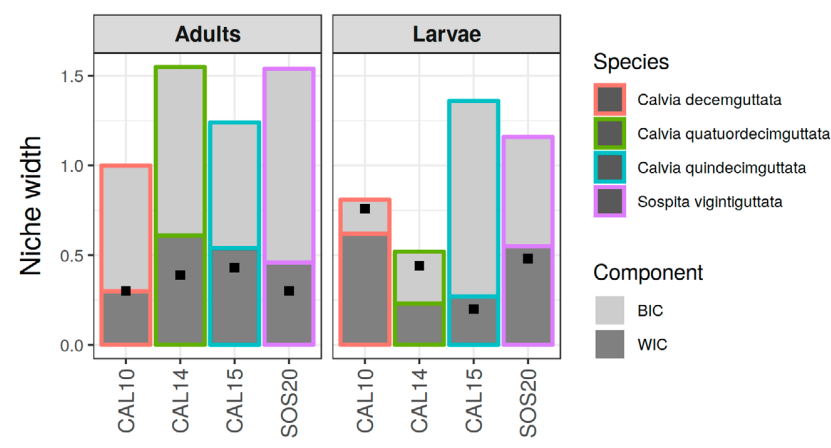

Fig 2. Niche width (TNW) of the four species, adult and larvae considered separately, with details of its two components $\mathrm{BIC}$ and WIC (see text for details). The dot is the WIC/TNW ratio. Species symbols as in Fig. 1.

width is broader for adults than larvae, whereas the opposite is recorded for $C$. quindecimguttata: $\mathrm{TNW}$ (adult) = 1.24; $\mathrm{TNW}($ larvae $)=1.36$.

The ratio $\mathrm{WIC} / \mathrm{TNW}$ was in most cases lower (i.e. indicating higher individual specialization) for adults than larvae. However, in C. quindecimguttata this ratio is lower for larvae than adults.

Adults of all species and larvae of three species showed a strong level of individual specialization, since the actual IS indices were statistically smaller than the simulated distributions of $P S_{i}$ 's (all $\mathrm{p}<0.001$ ). Only for the larvae of C. quatuordecimguttata was the individual specialization index less strong, although still significantly $(p=0.035)$ different from the resampled simulation distribution (Fig. 3 ). In other words, larvae of this species had an IS not much different from that of individuals that randomly select their prey from the prey available.

\section{DISCUSSION}

Field-collected data on the habitat, host plant and prey preferences of a predatory species are the basic information needed for characterizing its ecology and biocenotic relationships. One may assume that the most abundant species of prey on host plants will constitute the main source of the predator's food. However, this assumption may give an inaccurate picture of the feeding habits of the predator (Thompson, 1951 in Hodek \& Evans, 2012). It is necessary to know if the potential prey is accepted as food and if it is nutritionally suitable. Ultimately, evidence of food suitability has to be experimentally shown if a species of prey is to be classified as essential, i.e. attractive to ovipositing females and suitable food for their larvae to complete their development, or alternatively it is the only source of energy for survival (Mills, 1981; Evans et al., 1999; Hodek \& Evans, 2012).

The method applied in this study (frass analysis) does not allow evaluation of prey suitability, but enables the identification of the various types prey actually selected by the ladybirds in the wild. Specifically, using this method we could address the questions concerning food niche width, diet diversity and food specialization.

\section{Food niches and diet diversity}

Our results indicate that the adults of the four ladybirds studied in using most of the available prey and having diets that were usually more diversified (higher D index and TNW) than that of their larvae, appear to be generalist predators. Larvae of most species were more specialized, although in C. quindecimguttata the TNW of larvae was higher than that of adults. The narrower larval niches are not surprising considering that ladybird larvae usually have more stringent nutritional requirements than adults (Lundgren, 2009). The diet of larvae has to be focused on essential food, selected by the females laying their eggs in suitable patches in terms of larval development and survival. In contrast, adults may persist for long periods feeding on various kinds of non-essential food. Moreover, they are more mobile than larvae and thus may exploit patches with different food resources (Michaud, 2005).
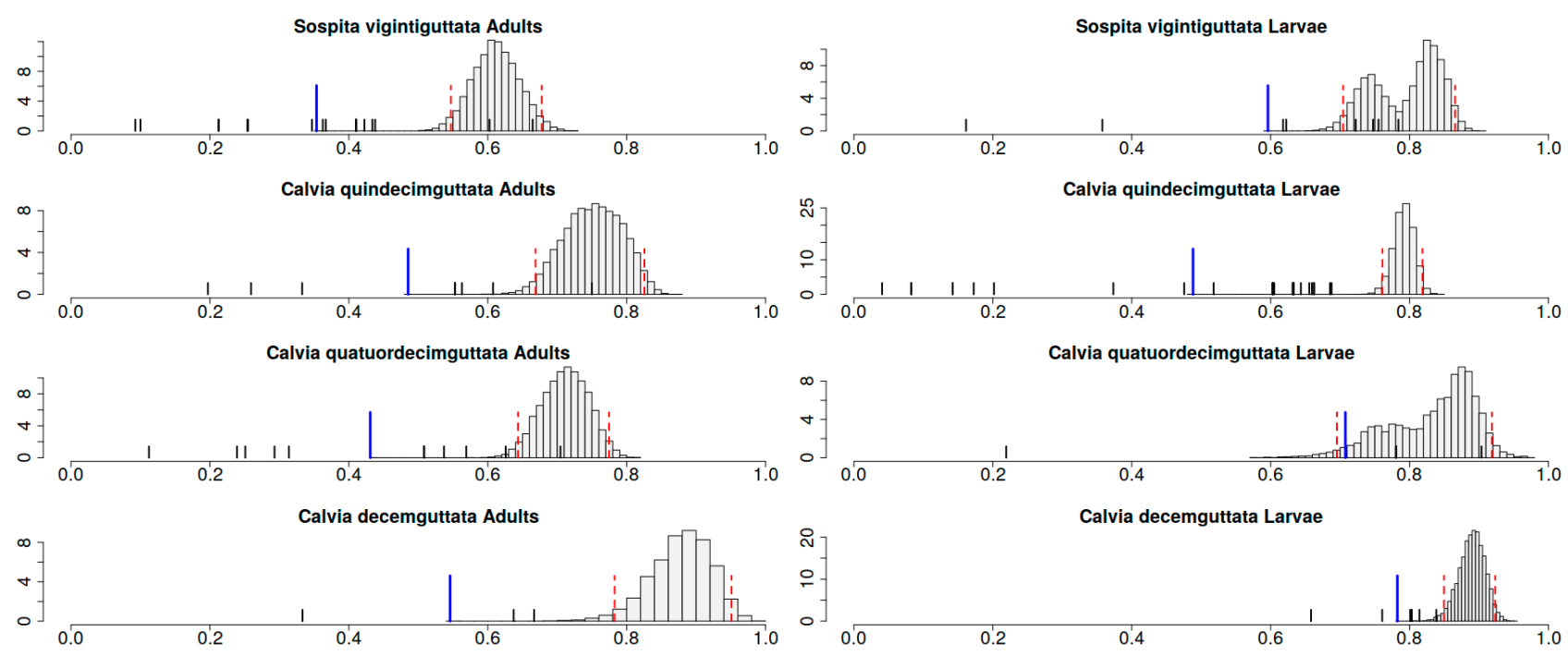

Fig. 3. Histograms of the distributions of individual specialization (IS) indices obtained using the Monte Carlo resampling procedure. Vertical broken lines show the $95 \%$ confidence limits of the simulated distribution, the thick vertical line (long solid line) shows the actual mean index value for the original individual data (short solid lines). 
Larvae and adults of the ladybirds studied, although considered as principally aphidophagous, showed certain preferences for non-aphid prey. Sospita vigintiguttata and C. quatuordecimguttata, although not strictly specialized on psyllids as suggested by Semyanov (1980) and Palmeri et al. (1996), consumed $P$. alni relatively frequently. Remains of chrysomelid larvae were often detected in the frass of $C$. quindecimguttata, but again not so often as cited by Kanervo (1940) who includes this ladybird among specialized chrysomelid eaters. In this latter case, however, the observed proportion could be largely underestimated knowing that chrysomelid larvae (and eggs) are typically sucked out and not eaten as a whole, especially by ladybird larvae (Florek et al., 2011).

Predation on ladybird larvae was clearly displayed by adults of $C$. decemguttata, larvae of $C$. quatuordecimguttata and, to a lesser extent, $S$. vigintiguttata. Spiny projections on the skin of larvae of $C$. quatuordecimguttata and $S$. vigintiguttata might make them superior predators in intraguild interactions with spineless larvae, such as those of C. decemguttata or C. quindecimguttata. The importance of spines for the outcome of intraguild confrontations between ladybird larvae are emphasized by many authors (Ware \& Majerus, 2008; Katsanis et al., 2013; Hautier et al., 2017; Ceryngier et al., 2018).

The presence of Psocodea remains in adult and larval frass of all species (except C. quatuordecimguttata larvae) is a finding that is, to our knowledge, not documented in the literature. The adults and larvae of C. quindecimguttata and $C$. decemguttata, as well as adults of $S$. vigintiguttata, seem to be quite efficient in catching Psocodea. This observation extends the list of alternative prey of ladybirds.

\section{Food specialization at the individual level}

The recorded level of individual specialization was significantly different from that based on a random selection of prey by adults of the all the species and larvae of three species (not significantly different from random choice for the larvae of C. quatuordecimguttata). Larvae are less mobile than adults and hence unable to choose among diverse food sources in the short period available to them and, more importantly, the food patch they use is selected by the mother. It could therefore be expected that larvae will show relatively low individual specialization since they are usually placed in situations that are most suitable for their development. Conversely, adults could be more likely to test different types of resources as they are able to move quickly from one food patch to another. Indeed, both the WIC/TNW and IS values were higher in larvae than adults for most of the species studied, indicating lower individual specialization of the larvae. The only exception was $C$. quindecimguttata, in which individual larvae were not less specialized than the adults. High level of individual specialization of larvae of $C$. quindecimguttata in comparison with that of larvae of other species was connected with a high value of the larval TNW (higher than in the adults of this species). Previous studies (Florek et al., 2011) also indicate that the food spectrum of the larvae of C. quindecimguttata is wider than that of larvae of other alder-inhabiting ladybirds. Interestingly, our study showed that larvae of the least habitat-specialized species, C. quatuordecimguttata, mostly rely on one food source (aphids) and thus it has a narrow trophic niche and the lowest level of individual food specialization.

\section{Concluding remarks}

Our results indicate that all the ladybird species studied are rather opportunistic and prey upon a wide range of the various types of prey encountered on alder trees. The most frequently recorded type of prey of both larvae and adults of the four species were aphids, probably because of their suitability as food, high abundance and ease of capture. On the other hand, in the frass of all the species studied less known prey, such as Psocodea, were often found. Early in the season, when aphid densities were low, a substantial proportion of the prey of $C$. quindecimguttata consisted of larvae and probably eggs of Chrysomelidae. At the same time, $P$. alni was an important food source for adults and larvae of $S$. vigintiguttata and for adults of $C$. quatuordecimguttata.

Habitat and food specialization are often interrelated in ladybirds (Sloggett \& Majerus, 2000; Sloggett, 2008; Ferrer et al., 2016). It is thus a little surprising that $S$. vigintiguttata and $C$. quindecimguttata, the species regarded as strict habitat specialists, turned out to have broader food niches than the much more habitat-generalists $C$. decemguttata and $C$. quatuordecimguttata. Our study showed that the habitat specialists could temporarily switch to preying on invertebrates that are unsuitable or disregarded by competitors. Close habitat and prey specializations, as reported for Iberorhyzobius rondensis that exclusively occurs on Pinus pinaster and preys on Matsucoccus feytaudi (Tavares et al., 2014), are probably very rare among predatory ladybirds.

ACKNOWLEDGEMENTS. This study was supported by the grant 2011/01/B/NZ8/06206 from the National Science Centre, Poland. JLH was further supported by the ANR funded French Laboratory of Excellence projects "LABEX TULIP" and "LABEX CEBA" (ANR-10-LABX-41, ANR-10-LABX-25-01).

\section{REFERENCES}

Adriaens T., San Martin y Gomez G., Bogaert J., Crevecoeur L., BeuckX J.-P. \& Maes D. 2015: Testing the applicability of regional IUCN Red List criteria on ladybirds (Coleoptera, Coccinellidae) in Flanders (north Belgium): opportunities for conservation. - Insect Conserv. Diver. 8: 404-417.

Albuquerque G.S., Tauber M.J. \& Tauber C.A. 1997: Life-history adaptations and reproductive costs associated with specialization in predacious insects. - J. Anim. Ecol. 66: 307-317.

Blackman R.L. 1965: Studies on specificity in Coccinellidae. Ann. Appl. Biol. 56: 336-338.

Bolnick D.I., Yang L.H., Fordyce J.A., Davis J.M. \& SvanbäcK R. 2002: Measuring individual-level resource specialization. -Ecology 83: 2936-2941.

Bolnick D.I., Svanbäck R., Fordyce J.A., Yang L.H., Davis J.M., Hulsey C.D. \& Forister M.L. 2003: The ecology of individuals: incidence and implications of individual specialization. Am. Nat. 161: 1-28. 
Ceryngier P., Nedvěd O., Grez A.A., Riddick E.W., Roy H.E., San Martin G., Steenberg T., Veselý P., Zaviezo T., ZúÑigaReinoso Á. \& Haelewaters D. 2018: Predators and parasitoids of the harlequin ladybird, Harmonia axyridis, in its native range and invaded areas. - Biol. Invas. 20: 1009-1031.

Colwell R.K. \& Futuyma D.J. 1971: On the measurement of niche breadth and overlap. - Ecology 52: 567-576.

Conrad M.S. 1959: The spotted lady beetle, Coleomegilla maculata (De Geer), as a predator of European corn borer eggs. - $J$. Econ. Entomol. 52: 843-847.

Costa A., Salvidio S., Posillico M., Matteucci G., De Cinti B. \& RomAno A. 2015: Generalisation within specialization: interindividual diet variation in the only specialized salamander in the world. - Sci. Rep. 5: 13260, 10 pp.

Davidson L.N. \& Evans E.W. 2010: Frass analysis of diets of aphidophagous lady beetles (Coleoptera: Coccinellidae) in Utah alfalfa fields. - Environ. Entomol. 39: 576-582.

Elton C. 1927: Animal Ecology. Macmillan, New York, xxii + $207 \mathrm{pp}$.

Evans E.W., Stevenson A.T. \& Richards D.R. 1999: Essential versus alternative foods of insect predators: benefits of a mixed diet. - Oecologia 121: 107-112.

FerRer A., Dixon A.F.G. \& HemptinNe J.-L. 2016: Habitat or prey specialization in predatory ladybird beetles: a case study of two closely related species. - J. Appl. Entomol. 140: 199-208.

Florek K., Tragarz J. \& Ceryngier P. 2011: Species composition and diets of ladybird beetles (Coleoptera: Coccinellidae) associated with black alder (Alnus glutinosa (L.) Gaertner) in a marshy forest. - Aphids Other Hemipt. Insects 17: 165-174.

Hautier L., San Martin G., Jansen J.-P., Branquart E. \& GréGOIRE J.-C. 2017: Spiny prey, fortunate prey. Dorsal spines are an asset in intraguild interactions among lady beetles. - Front. Ecol. Evol. 5: 135, 10 pp.

Hodek I. \& Evans E.W. 2012: Food relationships. In Hodek I., Emden H.F. van \& Honěk A. (eds): Ecology and Behaviour of the Ladybird Beetles (Coccinellidae). Blackwell, Chichester, pp. 141-274.

HODEK I., EMden H.F. van \& HoNĚK A. (eds) 2012: Ecology and Behaviour of the Ladybird Beetles (Coccinellidae). Blackwell, Chichester, $561 \mathrm{pp}$.

HonĚK A. \& REJMÁNEK M. 1982: The communities of adult aphidophagous Coccinellidae (Coleoptera): A multivariate analysis. - Acta Oecol. / Oecol. Appl. 3: 95-104.

Hutchinson G.E. 1978: An Introduction to Population Ecology. Yale Univ. Press, New Haven, 260 pp.

Johnson R.H. 1910: Determinate Evolution in the Color-Pattern of the Lady-Beetles. Carnegie Institution of Washington, Washington D.C., iv +104 pp.

Kalushrov P. 1998: Ten aphid species (Sternorrhyncha: Aphididae) as prey for Adalia bipunctata (Coleoptera: Coccinellidae). — Eur. J. Entomol. 95: 343-349.

Kalushrov P. \& HodeK I. 2001: New essential aphid prey for Anatis ocellata and Calvia quatuordecimguttata (Coleoptera: Coccinellidae). - Biocontr. Sci. Technol. 11: 35-39.

Kalushkov P. \& HodeK I. 2005: The effects of six species of aphids on some life history parameters of the ladybird Propylea quatuordecimpunctata (Coleoptera: Coccinellidae). - Eur. J. Entomol. 102: 449-452.

Kanervo V. 1940: Beobachtungen und Versuche zur Ermittlung der Nahrung einiger Coccinelliden (Col.). - Ann. Entomol. Fenn. 6: 89-110.

Katsanis A., Babendreier D., Nentwig W. \& Kenis M. 2013: Intraguild predation between the invasive ladybird Harmonia axyridis and non-target European coccinellid species. - BioControl 58: 73-83.
LUNDGREN J.G. 2009: Nutritional aspects of non-prey foods in the life histories of predaceous Coccinellidae. - Biol. Contr. 51: 294-305.

Majerus M.E.N. 1994: Ladybirds. The New Naturalist, Harper Collins, London, $367 \mathrm{pp}$.

Michaud J.P. 2005: On the assessments of prey suitability in aphidophagous Coccinellidae. - Eur. J. Entomol. 102: 385-390.

MitLs N.J. 1981: Essential and alternative foods for some British Coccinellidae. - Entomol. Gaz. 32: 197-202.

NEDVĚD O. 1999: Host complexes of predaceous ladybeetles (Col., Coccinellidae). - J. Appl. Entomol. 123: 73-76.

NEDVĚD O. 2015: Ladybird Beetles (Coccinellidae) of Central Europe. Academia, Praha, 303 pp.

ObrYcki J.J. \& KRING T.J. 1998: Predaceous Coccinellidae in Biological Control. - Annu. Rev. Entomol. 43: 295-321.

Obrycki J.J., Tauber M.J., Tauber C.A. \& Ruberson J.R. 1997: Prey specialization in insect predators. In Radcliffe E.B., Hutchison W.D. \& Cancelado R.E. (eds): Radcliffe's IPM World Textbook. URL: https://ipmworld.umn.edu, University of Minnesota, St. Paul, MN.

Palmeri V., Russo A. \& Longo S. 1996: On food preferences of Calvia quatuordecimguttata and Sospita vigintiguttata (Coleoptera, Coccinellidae) in Alder woods of Southern Italy. In: Proceedings of the XX International Congress of Entomology, Firenze, Italy, August 25-31, 1996. p. 528.

Pielou E.C. 1972: Niche width and niche overlap: a method for measuring them. - Ecology 53: 687-692.

PutMAn W.L. 1964: Occurrence and food of some coccinellids (Coleoptera) in Ontario peach orchards. - Can. Entomol. 96: $1149-1155$.

Rana J.S., Dixon A.F.G. \& Jarošík V. 2002: Costs and benefits of prey specialization in a generalist insect predator. - J. Anim. Ecol. 71: 15-22.

RicCI C. 1986a: Food strategy of Tytthaspis sedecimpunctata in different habitats. In Hodek I. (ed.): Ecology of Aphidophaga 2. Academia, Praha, pp. 311-316.

Ricci C. 1986b: Seasonal food preferences and behaviour of Rhyzobius litura. In Hodek I. (ed.): Ecology of Aphidophaga 2. Academia, Praha, pp. 119-123.

Ricci C. \& Pontr L. 2005: Seasonal food of Ceratomegilla notata (Coleoptera: Coccinellidae) in mountain environments of Northern Italian Alps. - Eur. J. Entomol. 102: 527-530.

Ricci C., Ponti L. \& Pires A. 2005: Migratory flight and prediapause feeding of Coccinella septempunctata (Coleoptera) adults in agricultural and mountain ecosystems of Central Italy. - Eur. J. Entomol. 102: 531-538.

RichaRdS O.W. 1926: Studies on the ecology of English heaths: III. Animal communities of the felling and burn successions at Oxshott Heath, Surrey. - J. Ecol. 14: 244-281.

Roughgarden J. 1972: Evolution of niche width. - Am. Nat. 106: $683-718$.

SCHOENER T.W. 1974: Resource partitioning in ecological communities. - Science 185: 27-39.

SEMYANOv V.P. 1980: Biology of Calvia quatuordecimguttata L. (Coleoptera, Coccinellidae). - Entomol. Obozr. 59: 757-763.

SLOGGETT J.J. 2008: Habitat and dietary specificity in aphidophagous ladybirds (Coleoptera: Coccinellidae): Explaining specialization. - Proc. Neth. Entomol. Soc. Meet. 19: 95-113.

Sloggett J.J. \& MaJERus M.E.N. 2000: Habitat preferences and diet in the predatory Coccinellidae (Coleoptera): an evolutionary perspective. - Biol. J. Linn. Soc. 70: 63-88.

SNYDER W.E. 2009: Coccinellids in diverse communities: Which niche fits? - Biol. Contr. 51: 323-335.

SOBERÓN J. 2007: Grinnellian and Eltonian niches and geographic distributions of species. - Ecol. Lett. 10: 1115-1123. 
Tavares C., Jactel H., van Halder I., Mendel Z. \& Branco M. 2014: A case of ecological specialization in ladybirds: Iberorhyzobius rondensis (Coleoptera: Coccinellidae), potential biocontrol agent of Matsucoccus feytaudi (Hemiptera: Matsucoccidae). - Bull. Entomol. Res. 104: 367-375.

TRILTSCH H. 1999: Food remains in the guts of Coccinella septempunctata (Coleoptera: Coccinellidae) adults and larvae. - Eur. J. Entomol. 96: 355-364.

WARE R.L. \& MAJERUS M.E.N. 2008: Intraguild predation of immature stages of British and Japanese coccinellids by the invasive ladybird Harmonia axyridis. — BioControl 53: 169-188.

Weber D.C. \& Lundgren J.G. 2009: Assessing the trophic ecology of the Coccinellidae: Their roles as predators and as prey. - Biol. Contr. 51: 199-214.

Zaccarelli N., Mancinelli G. \& Bolnick D.I. 2013: RInSp: an R package for the analysis of individual specialisation in resource use. - Methods Ecol. Evol. 4: 1018-1023.

Received February 10, 2019; revised and accepted April 30, 2019 Published online June 13, 2019

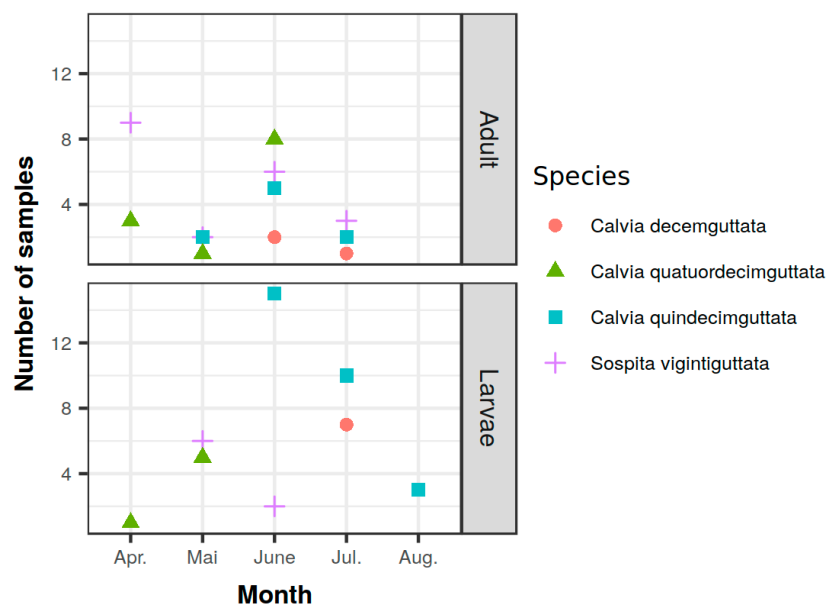

Fig. S1. Graphical representation of the range in dates over which the results of sampling in the four years was pooled. Details of individual samples are available in Table S1. 
Table S1. Raw data set included in the analysis, with the following columns: ID (a unique sample identifier); Date (month $+1^{\text {st }}, 2^{\text {nd }}$ or $3^{\text {rd }}$ ten days of the month); Spec (Species name); Stage (Adult or larva); Acari to Thysanoptera (10 columns giving the number of tags corresponding to each type of prey).

\begin{tabular}{|c|c|c|c|c|}
\hline ID & Date & Spec & Stage & Acari \\
\hline 1 & $04 \mathrm{III}$ & Sospita vigintiguttata & Adult & 0 \\
\hline 2 & $04^{-I I I}$ & Sospita viqintiquttata & Adult & 0 \\
\hline 3 & $04^{-1 I I I}$ & Sospita vigintiguttata & Adult & 0 \\
\hline 4 & 04_III & Sospita vigintiguttata & Adult & 0 \\
\hline 5 & $04^{-1 I I}$ & Sospita vigintiguttata & Adult & 0 \\
\hline 6 & $04^{-1 I I}$ & Sospita vigintiguttata & Adult & 0 \\
\hline 7 & $04^{-1} \|$ & Sospita vigintiguttata & Adult & 0 \\
\hline 8 & $04^{-}$III & Calvia quatuordecimguttata & Adult & 2 \\
\hline 9 & $04^{-}$III & Calvia quatuordecimguttata & Adult & 0 \\
\hline 10 & $04^{-1 I I}$ & Calvia quatuordecimguttata & Adult & 0 \\
\hline 11 & $04^{-1 I I}$ & Calvia quatuordecimguttata & Larvae & 0 \\
\hline 12 & $04^{-111}$ & Sospita vigintiguttata & Adult & 0 \\
\hline 13 & $04-111$ & Sospita vigintiguttata & Adult & 0 \\
\hline 14 & $05 \|$ & Sospita viqintiquttata & Larvae & 1 \\
\hline 15 & 05 & Sospita viqintiquttata & Larvae & 0 \\
\hline 16 & 05 & Calvia quatuordecimguttata & Larvae & 0 \\
\hline 17 & $06 i$ & Calvia decemguttata & Adult & 0 \\
\hline 18 & $06-i$ & Calvia quindecimguttata & Adult & 0 \\
\hline 19 & $06^{-1}$ & Calvia quindecimguttata & Larvae & 0 \\
\hline 20 & 06 & Calvia quindecimguttata & Larvae & 0 \\
\hline 21 & 05 & Calvia quindecimquttata & Adult & 0 \\
\hline 22 & $05 \|$ & $\begin{array}{l}\text { Sospita vigintiguttata } \\
\text { Suta }\end{array}$ & Adult & 0 \\
\hline 23 & 05 & Sospita vigintiguttata & Adult & 0 \\
\hline 24 & 05 & Sospita vigintiguttata & Larvae & 0 \\
\hline $\begin{array}{l}<4 \\
25\end{array}$ & 05 -III & Calvia quatuordecimguttata & Adult & 0 \\
\hline 26 & $05^{-1 I I}$ & Calvia quatuordecimguttata & Larvae & 0 \\
\hline 27 & $05^{-1 I I I}$ & Calvia quatuordecimguttata & Larvae & 0 \\
\hline 28 & $05^{-11}$ & Calvia quatuordecimquttata & Larvae & 0 \\
\hline 29 & $05^{-}$III & Calvia quatuordecimguttata & Larvae & 0 \\
\hline 30 & $05^{-1 I I}$ & Calvia quindecimguttata & Adult & 0 \\
\hline 31 & 05 III & Sospita vigintiguttata & Larvae & 0 \\
\hline 32 & $05^{-}$III & Sospita viqintiquttata & Larvae & 0 \\
\hline 33 & $05^{-1 I I}$ & Sospita viqintiquttata & Larvae & 0 \\
\hline 34 & 061 & Calvia quindecimguttata & Larvae & 0 \\
\hline 35 & $06^{-i}$ & Calvia quindecimguttata & Larvae & 0 \\
\hline 36 & 06 & Calvia quindecimguttata & Larvae & 0 \\
\hline 37 & $06^{-1}$ & Calvia quindecimguttata & Larvae & 0 \\
\hline 38 & 06 & Calvia decemguttata & Adult & 1 \\
\hline 39 & 06 & Sospita vigintiguttata & Larvae & 3 \\
\hline 40 & $06^{-1}$ & Sospita vigintiguttata & Larvae & 0 \\
\hline 41 & $06^{-1}$ & Sospita vigintiguttata & Adult & 0 \\
\hline 42 & $06^{-1}$ & Sospita vigintiguttata & Adult & 0 \\
\hline 43 & 07 & Calvia quindecimguttata & Adult & 0 \\
\hline 44 & 07 & $\begin{array}{l}\text { Sospita vigintiguttata } \\
\text { Sota }\end{array}$ & Adult & 0 \\
\hline 45 & $07^{-1}$ & Sospita viqintiquttata & Adult & 0 \\
\hline 46 & $07^{-i}$ & Sospita vigintiguttata & Adult & 3 \\
\hline 47 & $06^{-1}$ & Calvia quatuordecimguttata & Adult & 0 \\
\hline 48 & 06 & Calvia quatuordecimguttata & Adult & 0 \\
\hline 49 & 06 & Calvia quatuordecimguttata & Adult & 0 \\
\hline 50 & $06^{-1}$ & Calvia quatuordecimguttata & Adult & 0 \\
\hline 51 & 06 & Calvia quatuordecimguttata & Adult & 0 \\
\hline 52 & $06^{-1}$ & Calvia quatuordecimquttata & Adult & 0 \\
\hline 53 & $06^{-}$ & Calvia quatuordecimguttata & Adult & 0 \\
\hline 54 & 06 & Sospita viqintiquttata & Adult & 0 \\
\hline 55 & $06^{-1}$ & Sospita viqintiquttata & Adult & 0 \\
\hline 56 & $06^{-1}$ & Sospita viqintiquttata & Adult & 1 \\
\hline 57 & $06^{-1}$ & Sospita viqintiquttata & Adult & 0 \\
\hline 58 & $06-1$ & Calvia quatuordecimguttata & Adult & 4 \\
\hline 59 & 06 & Calvia quindecimguttata & Adult & 0 \\
\hline 60 & $06-1$ & Calvia quindecimguttata & Adult & 1 \\
\hline 61 & 06 & Calvia quindecimguttata & Adult & 0 \\
\hline 62 & $06-1$ & Calvia quindecimguttata & Adult & 0 \\
\hline 63 & 06 & Calvia quindecimguttata & Larvae & 2 \\
\hline 64 & 06 & Calvia quindecimguttata & Larvae & 0 \\
\hline 65 & 07 - III & Calvia decemguttata & Adult & 0 \\
\hline 66 & $07^{-1 I I}$ & Calvia decemguttata & Larvae & 0 \\
\hline 67 & $07^{-1 I I}$ & Calvia decemquttata & Larvae & 0 \\
\hline 68 & $07^{-1 I I I}$ & Calvia decemquttata & Larvae & 0 \\
\hline 69 & $07^{-11}$ & Calvia decemquttata & Larvae & 2 \\
\hline 70 & $07^{-1 I I}$ & Calvia decemguttata & Larvae & 0 \\
\hline 71 & $07^{-1 I I I}$ & Calvia decemguttata & Larvae & 1 \\
\hline 72 & 07 III & Calvia decemquttata & Larvae & 3 \\
\hline 73 & $07^{-1 I I I}$ & Calvia quindecimguttata & Adult & 0 \\
\hline 74 & $07^{-1 I I I}$ & Calvia quindecimquttata & Larvae & 2 \\
\hline 75 & $07^{-}$III & Calvia quindecimguttata & Larvae & 0 \\
\hline 76 & $07^{-1 I I}$ & Calvia quindecimguttata & Larvae & 0 \\
\hline 77 & 07 III & Calvia quindecimguttata & Larvae & 0 \\
\hline 78 & $07-1.1$ & Calvia quindecimguttata & Larvae & 0 \\
\hline 79 & 07 III & Calvia quindecimguttata & Larvae & 0 \\
\hline 80 & 07 III & Calvia quindecimquttata & Larvae & 0 \\
\hline 81 & $07^{-11}$ & Calvia quindecimquttata & Larvae & 3 \\
\hline 82 & $07^{-1 I I}$ & Calvia quindecimguttata & Larvae & 0 \\
\hline 83 & 081 & Calvia quindecimguttata & Larvae & 0 \\
\hline 84 & 08 & Calvia quindecimguttata & Larvae & 0 \\
\hline 85 & $08^{-1}$ & Calvia quindecimguttata & Larvae & 0 \\
\hline 86 & 06 TIII & Calvia quindecimquttata & Larvae & 2 \\
\hline 87 & $06^{-1 I I}$ & Calvia quindecimguttata & Larvae & 2 \\
\hline 88 & $06^{-1 I I}$ & Calvia quindecimguttata & Larvae & 0 \\
\hline 89 & $06^{-1 I I}$ & Calvia quindecimguttata & Larvae & 0 \\
\hline 90 & $06^{-1} \|$ & Calvia quindecimguttata & Larvae & 0 \\
\hline 91 & $06^{-} \mathrm{III}$ & Calvia quindecimguttata & Larvae & 0 \\
\hline 92 & $06^{-}$III & Calvia quindecimquttata & Larvae & 0 \\
\hline 93 & 071 & Calvia quindecimguttata & Larvae & 2 \\
\hline
\end{tabular}

